Szegedi Tudományegyetem, Fogorvostudományi Kar, Konzerváló és Esztétikai Fogászati Tanszék, Szeged* Szegedi Tudományegyetem, Fogorvostudományi Kar, Szájsebészeti Tanszék, Szeged*

\title{
Flexibilis és merev üvegszál megerősítésú intraradikuláris csapok törési ellenállásának in vitro összehasonlító vizsgálata - pilot study
}

\author{
DR. FRÁTER MÁRK*, DR. FORSTER ANDRÁS*, JANTYIK ÁDÁM*, DR. BRAUNITZER GÁBOR**, DR. NAGY KATALIN**
}

\begin{abstract}
Bevezetés: Jelen vizsgálat célja a gyökérkezelt üvegszál megerősítésú kompozit csapokkal, különféle technikákkal és anyagokkal helyreállított kisörlő fogak töréssel szembeni ellenállásának és megerősítő hatásának összehasonlítása.

Anyag és módszer: 32 darab kihúzott és gyökérkezelt kisörlö fogat 4 csoportba osztottunk $(n=8)$ a használt csap(ok) száma és anyaga alapján (1-4. csoport). 1: egyetlen hagyományos merev üvegszálas csap, 2: egy merev fő és egy járulékos üvegszálas csap, 3: egyetlen elasztikus csap, 4: egy elasztikus fő és egy járulékos csap. A csapok beragasztását és a csonkfelépítést követően a fogakat statikus terhelési tesztnek tettük ki törésig. A töréssel szembeni ellenállás mellett a törés mintázatát is vizsgáltuk.

Eredmények: a 4. csoport nyújtotta a töréssel szembeni legjobb ellenállási eredményeket a tesztelt csoportok között. A több csapot használó restaurátumok (2. és 4. csoport) szignifikánsan jobban teljesítettek, mint az 1. csoport ( $p=0,041$; $p=0,032$ ). A törési mintázat tekintetében a csoportok többnyire homogének voltak.

Megbeszélés: jelen vizsgálat alapján több üvegszálas csap alkalmazása egyazon gyökércsatornában mindig előnyös a végleges restaurátum szempontjából, függetlenül a csap rugalmasságától. A csapok elaszticitása nem befolyásolta a létrejött törés mintázatát.
\end{abstract}

Kulcsszavak: üvegszál megerősítésű csap, multi-post technika, minimál invazív, töréssel szembeni ellenállás

\section{Bevezetés}

A gyökérkezelt fogak struktúrájukban eltérnek a vitális, nem restaurált fogaktól, emiatt a helyreállításuk során speciális szempontokat kell figyelembe venni. A különbségek között szerepel a csökkent nedvességtartalom és dentinkeménység, valamint a csökkent propriocepció [1], viszont más tanulmányok szerint az említett eltérések, különbségek elhanyagolhatók [2]. A fő probléma a gyökérkezelt fogak esetén a jelentős koronális foganyagveszteség, amely leggyakrabban szuvasodás, korábbi restaurátum fraktúrája vagy a trepanálás és hozzáférési nyílás kialakítása során okozott nagy menynyiségű dentineltávolítás következménye [3, 4]. Az említett okok következtében a gyökérkezelt fogak gyakrabban törnek normál használat esetén is. Emiatt javasolt ezen meggyengült fogakat a helyreállítás során intraradikuláris csappal ellátni, nemcsak a koronai restaurátum extra tartásának biztosítása, hanem a fog megerősítése céljából is [5]. Erre a célra üvegszál megerősítésú kompozit csapokat javasolnak, melyek nagymértékű fejlődésen mentek át az elmúlt 10 évben [6]. Az üvegszálas csapok beragasztására általában kompozit cementeket alkalmaznak, ugyanakkor a gyökércsatorna falával létrejött adhézió minősége és nagysága a mai napig vitatott. Ezt az adhéziót több tényező kompromit- tálja. Közülük legfontosabb a 200-nál is nagyobb c-faktor, mely könnyedén okozhatja a ragasztóréteg elválását („debonding”) a gyökércsatorna falától [7]. Ezt számos in vitro vizsgálat bizonyítja, melyekből az is kiderült, hogy a mechanikai súrlódás kiemelt jelentőségú az üvegszálas csapok stabilitása és sikeressége szempontjából [8]. Továbbá újabb tanulmányok azt is bebizonyították, hogy a gyári csapelőfúrók használata gyengíti a megmaradt dentint és növeli a fraktúra veszélyét [9]. Ezért kiemelt jelentőségű a dentin megőrzése és ezáltal a gyökércsatorna eredeti lefutásának és keresztmetszetének megőrzése a restauratív beavatkozás során is. Ugyanakkor az így kapott, egyedi átmetszetű gyökércsatornák esetén egyetlen üvegszálas csap sokszor nem tud megfelelő retencióra, súrlódásra szert tenni. Több csap alkalmazása („multi-post technika”) egyazon gyökércsatorna esetén már korábban is felmerült lehetőségként, viszont ezt a technikát bizonyos mértékben limitálja a minimál invazív szemlélet a csapelőfúrás során. Az egyedi átmetszetű gyökércsatornák helyreállítására kínál lehetőséget a piacon a 2011-ben megjelent elasztikus üvegszálas csap (everStick POST, GC Europe, Leuven, Belgium). A csap polimetil metakrilát (PMMA) alapú polimerizálatlan, szemi-interpenetráló polimer mátrixot tartalmaz, mely lehetővé teszi, hogy a csap egyénileg formázható legyen, valamint vizsgá- 
latok alapján a csap hajlíthatósága és ragaszthatósága (a csap anyagához elért kötőerő) jobb eredményeket ad, mint a hagyományos, merev üvegszálas csapok esetén [6]. Jelen vizsgálat célja, hogy összehasonlítsa a töréssel szembeni ellenállás nagyságát és a törés mintázatát különböző üvegszálas csapokkal és technikákkal helyreállított gyökérkezelt kisörlő fogak esetén. A nullhipotézisek a következők: 1. A töréssel szembeni ellenállás-értékek nem különböznek egy vagy több csappal helyreállított fogak esetén. 2. Az elasztikus csap használata nem hozott létre kedvezőbb törési mintázatot.

\section{Vizsgálati anyag és módszer}

A vizsgálat során parodontológiai vagy orthodonciai okok miatt eltávolított 32 darab egygyökerü kisörlő fogat használtunk fel. A frissen eltávolított fogakat 5,25\%-os $\mathrm{NaOCl}$ oldatba helyeztük 5 percre, majd 0,9\%-os fiziológiás sóoldatba tettük és szobahőmérsékleten tároltuk. A fogakat az eltávolítást követő 6 hónapon belül felhasználtuk. A fogak előkészítése során a lágyszöveteket kézi depurátorokkal eltávolítottuk.

A mintákat egy kiképzett operátor készítette elő. Minden fogat dekoronáltunk a zománc-cement határ (CEJ - cementoenamel junction) magasságában, merőlegesen a gyökér hossztengelyére vízhútéssel, alacsony fordulatszámon egy gyémánt fogtechnikai koronggal. Ezt követően a fogakat gyökérkezeltük és gyökértömést készítettünk. A gyökérkezelés során crown down technikát alkalmaztunk 2-3-4 Gates Glidden fúrókkal (Union Broach, York, USA), majd a gyökércsatornát a teljes munkahosszon Protaper file-okkal (S1, S2, F1, F2, F3) (Dentsply, Maillefer, Ballaigues, Svájc) és ISO Hedström reszelővel munkáltuk meg. A gyökércsatorna átöblítését $2 \mathrm{ml} 5 \%$-os $\mathrm{NaOCl}$ oldattal végeztük minden eszköz, file használatát követően. A gyökércsatorna kiszárítása után a gyökértömést egy-poén technikával a feltágítással megegyező nagyságú guttaperhával (F3 gutta-percha, Maillefer-Dentsply, Ballaigues, Svájc) és sealerrel (AH plus; Dentsply De Trey GmbH, Konstanz, Németország) végeztük el. A gyökércsatorna bemeneteket ideiglenesen Clearfil S3 Bonddal (Kuraray, Tokyo, Japán) és Clearfil AP-X kompozittal (Kuraray, Tokyo, Japán) zártuk le. A fogakat inkubátorba helyeztük 1 hétre $37^{\circ} \mathrm{C}$-on $100 \%$-os relatív páratartalom mellett.

Az egyhetes inkubálást követően az ideiglenes lezárás eltávolítása után fúrással kialakítottuk a csapokat befogadó csatornaszakaszt $10 \mathrm{~mm}$ mélységig a dekoronált felszín buccalis peremétől mérve. A csapot vagy csapokat befogadó csatornaszakasz kialakításához nem használtunk gyári csapelőfúrót, hogy minél jobban megőrizzük az eredeti csatornalefutást és keresztmetszetet. Csak a gyökértömő anyagot igyekeztünk eltávolítani 3-4 méretű Gates Glidden fúrókkal és ISO standard Hedström reszelőkkel. A preparálás végén maradt egy
4-6 mm hosszú apikális érintetlen, gyökértömő anyagot tartalmazó csatornaszakasz. A 4-es méretű Gates Glidden fúrót csak a gyökércsatorna bemenetének megnyitására használtuk, a 3-as fúrót pedig a teljes $10 \mathrm{~mm}$ hosszú szakaszon alkalmaztuk. Ezután a fogakat véletlenszerūen 4 csoportba osztottuk 8-as elemszámmal minden csoportban.

Két különböző anyagú és tulajdonságú üvegszálas csapot használtunk a vizsgálatban: egy hagyományos, merev csapot (0,8 GC Fiber Post, GC Europe, Leuven, Belgium) és egy flexibilis, elasztikus csapot (0,9 EverStick POST, GC Europe, Leuven, Belgium). A csapok nem kaptak semmilyen felületkezelést az operátortól. Az elasztikus csapokat a gyártó utasításainak megfelelően kizárólag steril tűfogóval érintették. A csapokat $10 \mathrm{~mm}$ mélyre helyezték a gyökércsatornába, és $5 \mathrm{~mm}$ el értek túl a gyökér dekoronált felszínén, így a teljes hosszuk $\sim 15 \mathrm{~mm}$ volt.

$A z$ 1. csoport esetén egyetlen merev üvegszálas csapot $(\mathrm{d}=0,8 \mathrm{~mm})$ használtunk. A 2. csoportnál egy merev fő és egy járulékos csapot $(\mathrm{d}=0,8 \mathrm{~mm}$ mindkettő) használtunk multi-post technikában. A fő csapot behelyeztük, majd emellé került a járulékos csap minél apikálisabban, de csak olyan mélységig, amíg nem volt érezhető feszülés a levezetésnél. A 3. csoportnál egyetlen elasztikus csapot $(\mathrm{d}=0,9 \mathrm{~mm})$ használtunk. A csapot behelyezést követően tüfogóval eltávolítottuk a gyökércsatornából és 40 másodpercig fotopolimerizáltuk, hogy megőrizze a gyökércsatorna alakját, átmetszetét. A 4. csoportban egy elasztikus fő és egy járulékos csapot (0,9 mm mindkettő) használtunk. A fö csapot behelyeztük, majd emellé került a járulékos csap minél apikálisabban, de csak olyan mélységig, amíg nem volt érezhető feszülés a levezetésnél. 20 másodperces előpolimerizálást követően a két csapot együtt tüfogóval eltávolítottuk a gyökércsatornából és 40 másodpercig fotopolimerizáltuk, hogy megőrizze a gyökércsatorna alakját, átmetszetét.

A csapok beragasztását dual kötésű csonkfelépítő kompozittal (Gradia Core, GC Europe, Leuven, Belgium) és a hozzá tartozó adhezív rendszerrel végeztük az anyag gyártójának utasításait követve. A gyökércsatornába helyezést és a csap vagy csapok behelyezését követően 60 másodperc fotopolimerizációt végeztünk minden oldalról (240 másodperc foganként).

A felépítmény méreteinek standardizálása érdekében a csonkfelépítést premoláris preparált csonk formájú identikus celluloidkoronákkal végeztük. Ezt követően a mintákat egy hétig inkubáltuk $37^{\circ} \mathrm{C}$-on $100 \%$ relatív páratartalom mellett. A gyökerek felszínét szeparáló folyadékkal (Ruber-Sep, Kerr, Orange, USA) vontuk be a parodontális rostok szimulálására, majd a mintákat a CEJ-tól apikálisan $2 \mathrm{~mm}$-re meghatározott szintig beágyaztuk speciális beágyazó múgyantába (Technovit 4004, Heraeus-Kulzer, Wehrheim, Németország). 
A fogakat beágyazást követően mechanikai tesztelésnek tettük ki (Lloyd 1000R, Lloyd Instruments Ltd, Fareham, Egyesült Királyság) és törésig terheltük őket. A mechanikai tesztelést $0,5 \mathrm{~mm} /$ perc sebességgel végeztük és a töréssel szembeni ellenállást Newton-ban regisztráltuk. A mechanikai tesztelés után megvizsgáltuk a törési mintázatot. Az elkülönítést (restaurálható és nem restaurálható törés) Scotti és mtsai. ajánlása alapján végeztük [10]. A statisztikai elemzést SPSS 17,0 programmal készítettük el. Mivel az adatok nem mutattak normál eloszlást, a csoportok öszszehasonlítását Kruskal-Wallis ANOVA-val végeztük, amit post-hoc páronkénti összehasonlításokkal egészítettünk ki.

\section{Eredmények}

A tesztelt csoportokat jellemző töréssel szembeni ellenállás értékeket $(\mathrm{N})$ és a hozzájuk tartozó standard deviációt (SD) az 1. ábra mutatja. Amint az az 1. ábrán látható, a 4. csoport (egy elasztikus fő csap és egy járulékos csap) hozta létre a legmagasabb töréssel szembeni ellenállást, viszont ez az érték csak az 1 . csoporthoz képest (egyetlen merev csap) adott szignifikánsan jobb eredményt $(p=0,032)$. A 2. csoport (egy fő merev csap és egy járulékos csap) is szignifikánsan jobban teljesített, mint az 1. csoport ( $p=0,041)$. Egyik multipost technikát alkalmazó csoport sem hozott létre szignifikánsan jobb eredményt az egyetlen elasztikus csapot alkalmazó 3. csoportnál. A többi csoport összehasonlítása esetén sem volt szignifikáns eltérés. Emiatt a törési ellenállásra vonatkozó nullhipotézist részben el kellett vetni.

A törési mintázatok a vizsgált csoportokban teljesen megegyeztek (1. táblázat), így a törési mintázatra vonatkozó nullhipotézis valid.

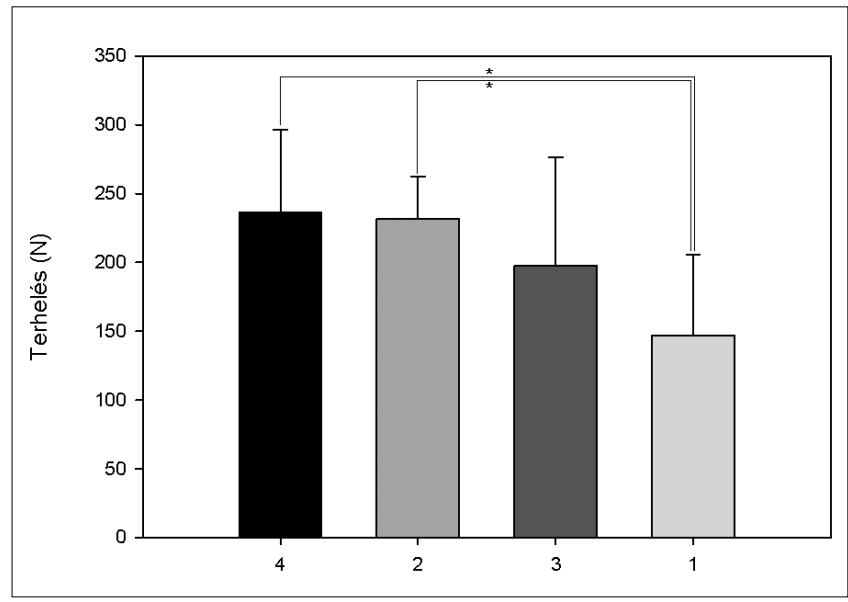

1. ábra: Töréssel szembeni ellenállás-értékek (átlag $\pm \mathrm{SD}$ ) a vizsgált csoportokban.

4: multi-post elasztikus csapokkal, 2: multi-post merev csapokkal,

3: egyetlen elasztikus csap, 1: egyetlen merev csap.

* szignifikáns különbségek $p<0,05$ szignifikancia szint esetén
1. táblázat

A törési mintázat eloszlása a vizsgált csoportokon belül.

\begin{tabular}{|l|c|c|}
\hline & Restaurálható & Nem restaurálható \\
\hline Multi-post / elasztikus & 6 & 2 \\
\hline Multi-post / merev & 6 & 2 \\
\hline $\begin{array}{l}\text { Egyetlen csap } \\
\text { / elasztikus }\end{array}$ & 6 & 2 \\
\hline Egyetlen csap / merev & 6 & 2 \\
\hline
\end{tabular}

\section{Megbeszélés}

A gyökérkezelt fogak helyreállítása kiemelt terület a restauratív fogászatban. Ezen fogak ellátására már az 1870-es évektől használnak különböző intraradikuláris csapokat. A modern, minimál invazív irányelvek alapján kiemelt fontosságú, hogy a csap behelyezhetősége érdekében nem szabad felesleges dentineltávolítást végezni, ugyanis számos tanulmány állítja, hogy a „csapelőfúrás" nemcsak tovább gyengíti a helyreállítandó fogat, hanem repedést létrehozva a gyökércsatornában, könnyedén lehet későbbi törés kiindulópontja is $[11,12,13]$.

Az említett megfontolások alapján a jelen vizsgálatban a szerzők csak minimál invazív „,csapelőfúrást” végeztek, azaz próbálták csak a gyökértömő anyagot eltávolítani a gyökércsatornából, megőrizve a közel eredeti anatómiát.

Emiatt a piacon forgalomban lévő legkisebb átmérőjủ csapok közül kellett választanunk (0,8 mm GC Fiber Post; $0,9 \mathrm{~mm}$ everStick POST). Goracci és mtsai. kimutatták, hogy az üvegszálas csapok esetén is a súrlódás a legfontosabb tényező, amely a csap stabilitásáért és helyben maradásáért felelős [14]. Ennek az oka a gyökércsatorna falához elért elégtelen adhézióban keresendő, mely multikauzális jelenség, például magas c-faktor, vastag smear layer, nehezen kontrollálható folyadékmennyiség a gyökércsatornában, a gyökéri dentin erodálódása az átöblítőszerek miatt stb. [15]. Sorensen és mtsai. kimutatták, hogy szignifikánsan nagyobb töréssel szembeni ellenállás érhető el, ha a csap jobban adaptálódik / szorosabb kontaktusban van a gyökércsatorna falával [16]. Az egy gyökércsatornában több csapot használó „multi-post technika” pontosan ezt célozza meg. A multi-post technika által az operátor képes nagy és irreguláris alakú gyökércsatornákban jobb kitöltöttséget elérni, mint egyetlen, a gyökércsatorna tengelyének megfelelően elhelyezett csappal. További előnye a technikának, hogy csökkenti a ragasztócement mennyiségét a csappal történő kitöltöttség javára, így csökken a cement zsugorodása által létrejött stressz, valamint az esetlegesen létrejött rés nagysága is.

Jelen vizsgálat adatai alátámasztják a multi-post technika előnyeit.

Úgy tünik, hogy a használt üvegszálas csapok ru- 
galmassága nem különösebben fontos tényező a multipost technika alkalmazása esetén, mivel nem volt szignifikáns különbség a merev és az elasztikus csapokat alkalmazó multi-post restaurációk esetén a töréssel szembeni ellenállás tekintetében. Érdekes tapasztalat, hogy a multi-post technikák egyike sem adott jelentősen eltérő eredményt az egyetlen elasztikus csapot alkalmazó 3. csoport adataihoz, eredményeihez képest. Lehetséges magyarázatként az szolgálhat, hogy a vizsgálatban használt speciális elasztikus csapból már akár egy is képes annyira adaptálódni a gyökércsatorna lefutásához, egyenetlenségeihez, hogy az képes kompenzálni a használt csap mennyiségét. További magyarázatul szolgálhat a jelenségre az is, hogy a modern minimál invazív szemlélet a csapelőfúrásban limitálja a behelyezhető csapok számát, és elősegítheti az akár egyetlen elasztikus csap általi kitöltöttséget is.

A csap vagy a restaurált fog törése a leggyakoribb okai a gyökérkezelt fogak sikertelenségének, elvesztésének [17]. Míg a fémcsapok gyakrabban okozzák a fog törését, addig az üvegszálas csapok esetén lényegesen gyakoribb a csap elválása a ragasztási felülettől (debonding) vagy a csap törése $[18,19]$. Számos tanulmány bizonyítja, hogy a dentinhez hasonló mechanikai tulajdonságokkal rendelkező üvegszálas csapok egységesebben osztják szét a csapot érő terhelést és ezáltal részben csökkentik a törések kialakulásának valószínűségét, részben kedvezőbb törési mintázatot képesek létrehozni [20, 21, 22]. Jelen vizsgálatban a restaurált csoportok között nem volt különbség a törési mintázat tekintetében.

Vizsgálatunkban a hagyományos merev üvegszálas csap alkalmazásakor törés esetén vagy a csonkfelépítő anyag vált el a csaptól (gyakrabban) vagy a csap tört el (ritkábban). Ezzel ellentétben az elasztikus csapok esetén a csap sosem vált el a csonkfelépítő anyagtól. Ezt a megfigyelést alátámasztják a Bell és mtsai által végzett vizsgálat eredményei [6]. A magyarázat a csap anyagában keresendő. A merev üvegszálas csapok nem képesek valódi kémiai kötést kialakítani rezin alapú anyagokkal, mivel a csapok mátrixa döntően keresztkötés alapú polimer, mely egy inaktív felszínt eredményez [23, 24]. Az everStick Post üvegszálas csap mátrixa egy szemiinterpenetráló polimer hálózat, amely a keresztkötések mellett lineáris kötéseket is tartalmaz. A lineáris kötéseket tartalmazó fázis polimetil metakrilát, amely képes adhezíven keresztül aktiválódni és valódi kémiai kapcsolatot létesíteni bármely metakrilát alapú anyaggal.

Jelen vizsgálatban egygyökerű kisörlő gyökérkezelt fogakat használtunk, mivel tanulmányok szerint ezek gyakrabban törnek gyökérkezelést követően normál rágóerő hatására is [9]. Ambica és mtsai. kimutatták, hogy gyökérkezelt fogak esetén, ha koronát is használunk a mechanikai teszteléshez, az jelentősen megváltoztatná a teherbírást és elfedheti az eltérő csonkfelépítések eredményeit, előnyeit [25]. Így a korona anyagából és a ragasztási protokollból fakadó eltérések is kizárhatók. Ezért vizsgálatunkban mi sem használtunk koronákat a restauratív eljárások összehasonlítására. Ugyanakkor ez egy ismert korlátja a vizsgálatnak, mivel így a kapott eredmények csak összehasonlításra alkalmasak és nem értelmezhetők közvetlenül klinikai körülményekre. A vizsgálat további korlátja lehet a használt csapok eltérő mérete (0,8 GC Fiber Post és 0,9 everStick POST), ami megnehezítheti a közvetlen összehasonlítást; mivel azonban nem történt hagyományos csapelőfúrás, így nem volt más lehetőség, mint a jelenleg forgalomban levő legkisebb méretű csapok közül választani.

\section{Konklúzió}

A vizsgálat korlátait figyelembe véve az eredmények alapján kijelenthetjük, hogy a minimál invazív „csapelöfúrás" esetén üvegszálas csapot használó multi-post restaurátumok jobban teljesítenek, függetlenül a csap anyagától, mint ha csak egyetlen csapot használnánk a gyökércsatornában. Továbbá kijelenthető, hogy a csap anyaga vagy a használt csapok száma nem befolyásolja a törési mintázatot.

\section{Irodalom}

1. Nam SH, Chang HS, Min KS, Lee Y, Cho HW, Bae JM: Effect of the number of residual walls on fracture resistances, failure patterns, and photoelasticity of simulated premolars restored with or without fiber-reinforced composite posts. J Endod 2010; 36(2): 297-301.

2. Dietschi D, Duc O, Krejci I, Sadan A: Biomechanical considerations for the restoration of endodontically treated teeth: a systematic review of the literature - Part 1. Composition and microand macrostructure alterations. Quintessence Int 2007; 38(9): 733-743.

3. Al-Omiri MK, Mahmoud AA, Rayyan MR, Abu-Hammad O: Fracture resistance of teeth restored with post-retained restorations: an overview. J Endod 2010; 36(9): 1439-1449.

4. ClaRK D, KHADEMI J: Modern molar endodontic access and directed dentin conservation. Dent Clin North Am 2010; 54(2): 249-273.

5. Cecchin D, Farina AP, Guerreiro CA, Carlini-Junior B: Fracture resistance of roots prosthetically restored with intra-radicular posts of different lengths. J Oral Rehabil. 2010; 37(2): 116-122.

6. Bell AM, Lassila LV, Kangasniemi I, VallitTu PK: Bonding of fibrereinforced composite post to root canal dentin. J Dent. 2005; 33(7): 533-539.

7. Boulllaguet S, Troesch S, Wataha JC, Krejci I, Meyer JM, PashLEY DH: Microtensile bond strength between adhesive cements and root canal dentin. Dent Mater 2003; 19(3): 199-205.

8. Naumann M, Sterzenbach G, Rosentritt M, Beuer F, FrankenbergER R: Is adhesive cementation of endodontic posts necessary? $J$ Endod 2008; 34(8): 1006-1010.

9. Zicari F, Van Meerbeek B, Scotti R, Naert I: Effect of fibre post length and adhesive strategy on fracture resistance of endodontically treated teeth after fatigue loading. J Dent 2012; 40(4): 312-321.

10. Scotti N, Coero Borga Fa, Alovisi M, Rota R, Pasqualini D, BERUTTI $E$ : Is fracture resistance of endodontically treated mandibular molars restored with indirect onlay composite restorations influenced by fibre post insertion? J Dent 2012; 40(10): 814-820.

11. Manning KE, Yu DC, Yu HC, Kwan EW: Factors to consider for predictable post and core build-ups of endodontically treated teeth. Part II: Clinical application of basic concepts. J Can Dent Assoc 1995; 61(8): 696-701, 3, 5-7. 
12. Bolhuis hPB, De Gee AJ, Feilzer AJ, Davidson Cl: Fracture strength of different core build-up designs. Am J Dent 2001; 14(5): 286-290.

13. Mohammadi N, Kahnamoil MA, Yeganeh PK, Navimipour EJ: Effect of fiber post and cusp coverage on fracture resistance of endodontically treated maxillary premolars directly restored with composite resin. J Endod 2009; 35(10): 1428-1432.

14. Goracci C, Fabianelli A, Sadek FT, Papacchini F, Tay FR, FerraRI M: The contribution of friction to the dislocation resistance of bonded fiber posts. J Endod 2005; 31(8): 608-612.

15. BitTer K, Kielbassa AM: Post-endodontic restorations with adhesively luted fiber-reinforced composite post systems: a review. Am J Dent. 2007; 20(6): 353-360.

16. Sorensen JA, Engelman MJ: Effect of post adaptation on fracture resistance of endodontically treated teeth. J Prosthet Dent 1990; 64(4): 419-424.

17. Naumann M, Blankenstein F, Kiessling S, Dietrich T: Risk factors for failure of glass fiber-reinforced composite post restorations: a prospective observational clinical study. Eur J Oral Sci 2005: 113(6): 519-524.

18. Chieruzzi M, Pagano S, Pennacchi M, Lombardo G, D'Errico P, KENNY JM: Compressive and flexural behaviour of fibre reinforced endodontic posts. J Dent 2012; 40(11): 968-978.

19. Ferrari M, Cagidiaco MC, Goracci C, Vichi A, Mason PN, Radovic I,
ET AL: Long-term retrospective study of the clinical performance of fiber posts. Am J Dent 2007; 20(5): 287-291.

20. Spazzin AO, Galafassi D, de Meira-Junior AD, Braz R, Garbin CA Influence of post and resin cement on stress distribution of maxillary central incisors restored with direct resin composite. Oper Dent 2009; 34(2): 223-229.

21. de Castro Albuquerque R, Polleto lt, Fontana RH, Cimini CA Stress analysis of an upper central incisor restored with different posts. J Oral Rehabil 2003; 30(9): 936-943.

22. Salameh Z, Ounsi HF, Aboushelib MN, Sadig W, Ferrari M: Fracture resistance and failure patterns of endodontically treated mandibular molars with and without glass fiber post in combination with a zirconia-ceramic crown. J Dent 2008; 36(7): 513-519.

23. Purton DG, Payne JA: Comparison of carbon fiber and stainless steel root canal posts. Quintessence Int 1996; 27(2): 93-97.

24. LASTUMAKI TM, LASSILA LV, VALLITTU PK: The semi-interpenetrating polymer network matrix of fiber-reinforced composite and its effect on the surface adhesive properties. J Mater Sci Mater Med 2003; 14(9): 803-809.

25. Ambica K, Mahendran K, Talwar $S$, Verma M, Padmini G, Periasamy $R$ : Comparative evaluation of fracture resistance under static and fatigue loading of endodontically treated teeth restored with carbon fiber posts, glass fiber posts, and an experimental dentin post system: an in vitro study. J Endod 2013; 39(1): 96-100.

\section{Fráter M, Forster A, Jantyik Á, Braunitzer G, Nagy K}

\section{Fracture strength of elastic and conventional fibre-reinforced composite intraradicular posts - an in vitro pilot study}

Objectives: The purpose of this in vitro investigation was to evaluate the reinforcing effect of different fibre-reinforced composite (FRC) posts and insertion techniques in premolar teeth when using minimal invasive post space preparation.

Materials and methods: Thirty two extracted and endodontically treated premolar teeth were used and divided into four groups $(n=8)$ depending on the post used (Group 1-4). 1: one single conventional post, 2: one main conventional and one collateral post, 3: one flexible post, 4: one main flexible and one collateral post. After cementation and core build-up the specimens were submitted to static fracture toughness test. Fracture thresholds and fracture patterns were recorded and evaluated.

Results: The multi-post techniques (group 2 and 4) showed statistically higher fracture resistance compared to group one. Regarding fracture patterns there was no statistically significant difference between the tested groups.

Conclusion: The application of multiple posts seems to be beneficial regarding fracture resistance independent from the used FRC post. Fracture pattern was not influenced by the elasticity of the post.

Keywords: fibre-reinforced composite, individual post, multi-post technique, minimal invasive, fracture resistance 